\title{
Implementation of Collaborative Learning as a High-Impact Practice in a Natural Resources Management Section of Freshman Seminar
}

\author{
Matthew McBroom ${ }^{1}$, Steven Bullard ${ }^{1}$, David Kulhavy ${ }^{1}$ \& Daniel Unger ${ }^{1}$ \\ 1 Arthur Temple College of Forestry and Agriculture, Stephen F. Austin State University, Box 6109 SFA Station, \\ Nacogdoches, TX 75962, USA \\ Correspondence: Matthew McBroom, Ph.D., CF, Interim Associate Dean, Arthur Temple College of Forestry and \\ Agriculture, Stephen F. Austin State University, Box 6109 SFA Station, Nacogdoches, TX 75962, USA. Tel: \\ 1-936-468-3301. E-mail: mcbroommatth@sfasu.edu
}

Received: August 3, 2015

Accepted: August 24, 2015

Online Published: September 11, 2015

doi:10.5430/ijhe.v4n4p64

URL: http://dx.doi.org/10.5430/ijhe.v4n4p64

\begin{abstract}
Forestry and environmental science students enrolled in a one credit hour freshman seminar course participated in a land management evaluation and water quality sampling excursion using canoes and water sampling equipment. The purpose of this assessment was to engage students with hands-on, field based education in order to foster connections to their chosen profession and natural resources. This culminated in a poster symposium of the experience. Broad competency areas for high impact practices in natural resource management were emphasized for learning. Students were engaged in the exercise and some commented that the project helped them develop a sense of place and forming connections within their peer group. Based on numerous other studies and this qualitative assessment, the use of water quality sampling and collection of real-world data can enhance student's perception of the teaching a learning effectiveness in natural resources management course.
\end{abstract}

Keywords: Natural resource management, Freshman seminar, Water quality monitoring, Hands on, River ecosystem

\section{Introduction}

Over the past two decades, enrollment in natural resources undergraduate programs in the United States has declined by a rate of about $4 \%$ per year (Wolter, Millenbah, Montgomery, \& Schneider, 2011b). This decline has occurred in spite of increasing job availability in both the private and public sectors due to retirements and increased demands in the US for professionals with these skills. The loss of students that begin natural resources management (NRM) programs to other majors and the failure to attract new students into these programs has been the subject of numerous studies (Wolter, Millenbah, Montgomery, \& Schneider, 2011a). Several reasons have been evaluated that could explain this nationwide trend, ranging from broader societal perceptions that may or may not be accurate (Sharik \& Frisk, 2011) to concerns that natural resources pedagogy has not kept up with changing student expectations and competencies (Vanclay, 2007).

Among the ideas for how to adapt natural resources pedagogy to the next generation of college students has been to provide incoming college freshmen with a course that will develop in them with the knowledge, skills, and abilities to succeed in college. Most effective first-year seminars and experiences place a strong emphasis on critical inquiry, frequent writing, and collaborative learning that develop intellectual and practical competencies (Kuh, Cruce, Shoup, Kinzie, \& Gonyea, 2008). In addition, particularly for natural resource management majors, a connection with the profession and resource early in the college experience is an important factor for success. This paper reports on a freshman seminar (SFA 101) course in which students conducted a longitudinal rapid bioassessment on the Neches River in East Texas and the high impact teaching practices of collaborative and field based learning and authentic connections to the profession and natural resources that were integrated into the course.

\section{Literature Review}

\subsection{Natural Resources Programs}

Natural resources management is a broad, interdisciplinary field that requires successful practitioners to integrate the sciences of ecology, biology, chemistry, and geology with human dimensions and economic constraints. Degrees in NRM professions of environmental science and forestry require an "expertise of breadth" that involves taking a wide range of core courses in subjects such as biology, chemistry, sociology, economics, business management, and policy 
(Robison, 2005). This combination of courses can be relatively bewildering for incoming freshmen. This bewilderment may be more intense for students entering science, technology, engineering, and mathematics (STEM) and natural resources fields, since students perceive a lack of connection to their intended careers during the early stages of their basic academic course work (Sweeder \& Strong, 2012).

Students who choose NRM majors typically desire to work outdoors, use modern technology, and make a difference to the world around them while dealing effectively with the complex economic, ecological and social issues inherent to NRM (Bullard et al., 2014). Due to the broad interdisciplinary nature of NRM careers, students need to work collaboratively (Thompson, Jungst, Colletti, Licklider, \& Benna, 2003). At the same time, higher order thinking skills need to be developed by the students. Using higher order thinking skills "requires we do something with the facts. We must understand them, connect them to each other, categorize them...and apply them as we seek new solutions to new problems" (Thomas \& Thorne 2009). Problem based learning is an effective technique for engaging student interest in NRM as a major, teaching higher order thinking skill, and for developing student technical competencies (Lobry de Bruyn \& Prior, 2001). Experiential learning in particular is a key component for NRM teaching and helping students to form necessary connections both to the resource and the profession (Newman, Bruyere, \& Beh, 2007).

\subsection{Problem-Based Collaborative Learning in the Outdoors}

Most NRM majors desire to work outdoors and often cite caring for nature (Sharik \& Frisk, 2011) and a passion for the outdoors as a reason for choosing their major (Wolter, Millenbah, Montgomery, \& Schneider, 2011a). This requires an understanding of how to effectively and safely work in the outdoor environment. Collaborative learning is also necessary to accomplish tasks that are too large and time consuming to complete individually. Outdoor learning can help students develop meaningful emotional and intellectual connections and a sense of place within specific areas, an important aspect NRM education (Semken \& Freeman, 2008).

For problem-based collaborative learning to be successful, the instructor must clearly define the problem as ill-defined problems are often cited in student criticism of problem-based learning (Lobry de Bruyn \& Prior, 2001). Students must have the necessary skills for problem-solving and this requires the instructor to work through aspects of the problem to prepare them for challenges. Finally, students must understand effective strategies for collaborative problem-based learning. Therefore, it is necessary to first teach effective collaborative learning frameworks like Cog's Ladder (Charrier, 1972).

\subsection{Use of Technology in Natural Resource Management}

Advances in technology have revolutionized most fields over the last two decades, and NRM is no exception. To be successful in their careers, students must understand how to solve meaningful problems using appropriate technologies. In addition, students entering NRM programs expect to be taught how to use the latest technologies in the field (Unger, Hung, Zhang, \& Kulhavy, 2014), (Unger, Kulhavy, Hung, \& Zhang, 2014). Therefore, to engage in meaningful tasks, the effective appropriate technologies must also be taught. The concern is that often times technologies used in NRM education like global positioning systems (GPS) and water quality instruments become black boxes, with students not understanding what is actually being measured or how the instrument is evaluating a particular parameter. Hands-on use of GPS provides practical application of technology that fosters collaborative learning and acquisition of a life-long skill (Unger, Hung, Zhang, \& Kulhavy, 2014). As has been observed by Maxwell (2003), "A person who knows how may always have a job, but the person who knows why will always be his boss." Therefore, it is important that at the university level students receive adequate instruction not only in how to use a technology, but that they understand the basic functions and appropriate applications of that device or instrument.

\subsection{Making Authentic Connections with People and the Environment}

The value of active, student-centered, problem-based, and authentic learning has been documented at all levels of education (Hancock, Smith, Timpte, \& Wunder, 2010) providing students with meaningful experiences to bridge content learned in classrooms and knowledge addressing contemporary issues (Schwartz, Lin, Brophy, \& Bransford, 1999). Collaborative field based exercises combined with presentations like poster symposium with active discussion of results engages students effectively by combining three broad areas of competency needed in natural resources professions. Posters in particular enhance understanding and have greater retention of the subject by topic by providing opportunities for peer learning and as a medium for developing communication skills (Berry \& Houston, 1995). In addition, skills are acquired in presentation preparation. Figure 1 illustrates how this project is at the intersection of technical, general, and personal areas of competency. This leads to a more successful college career 
(in courses later in the NRM curriculum), since understanding and perspective are both enhanced by layering communication skills and other general competencies, with personal abilities like acting in a professional manner, with a real-world NRM issue that is interdisciplinary in nature.

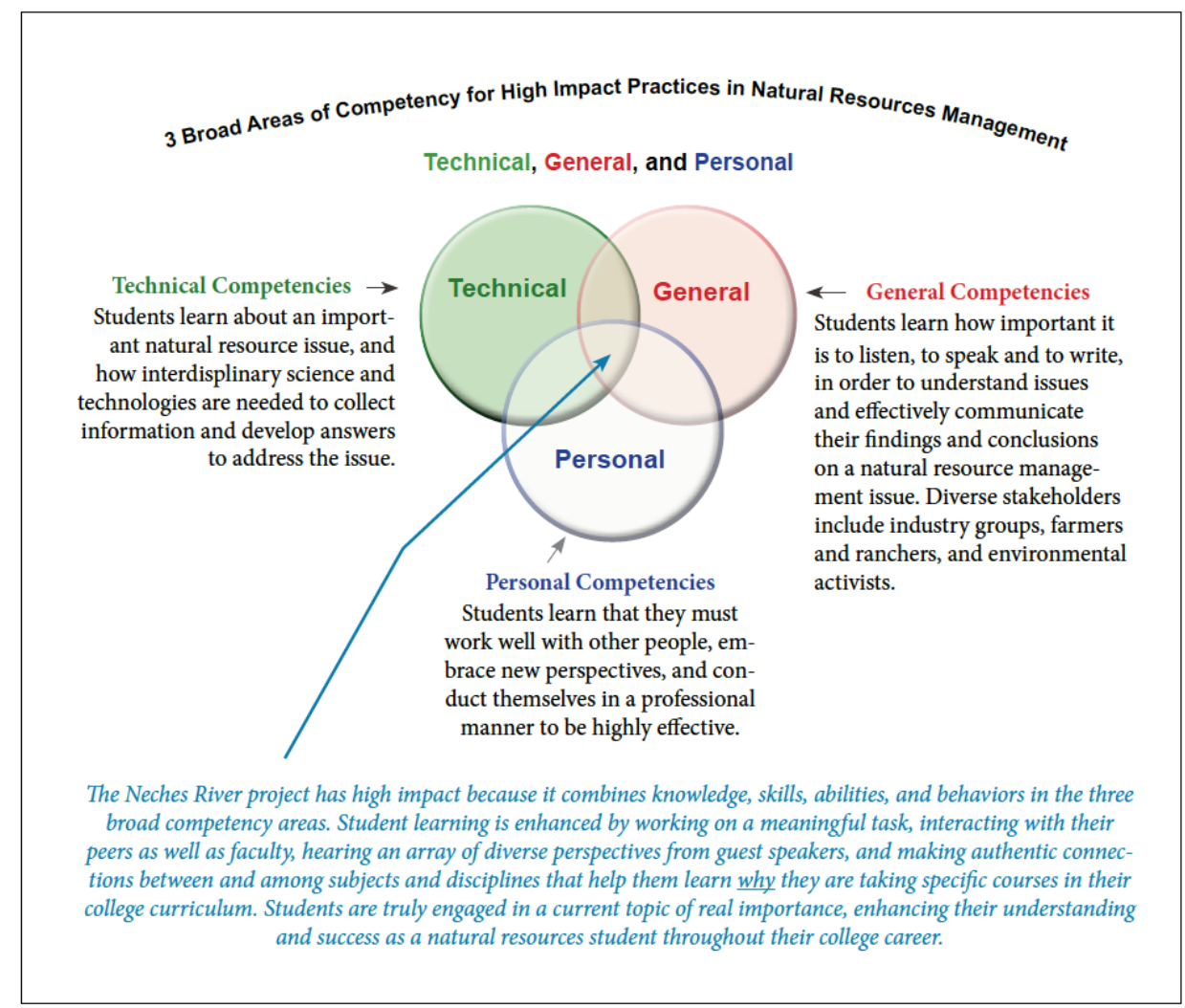

Figure 1. Conceptual framework for technical, general, and personal competencies emphasized in the Neches River survey project in SFA 101 (modified from Bullard et al. 2014).

\subsection{Natural Resource Management in a Freshman Seminar Class}

Much has been written about the lack of preparation for incoming college freshmen for succeeding in a university-level academic career, particularly for first-generation college students (Pascarella, Pierson, Wolniak, \& Terenzini, 2004). Courses that help ease the transition into academic life can be effective for increasing student retention and success (Schnell \& Doetkott, 2003). For natural resources management majors in particular, students need to make connections to their final career early in their academic program. Effective seminar courses can help students determine or reinforce major choices, develop a vision of themselves as professionals, and make meaningful connections with faculty (Sweeder \& Strong, 2012). Most effective first-year seminars and experiences also place a strong emphasis on critical inquiry, frequent writing and collaborative learning that develop intellectual and practical competencies (Kuh, Cruce, Shoup, Kinzie, \& Gonyea, 2008).

An effective freshman seminar course for NRM majors in particular, in addition to providing basic skills for college success, should teach effective problem-based collaborative learning in the outdoors, teach how to use technology to engage meaningful tasks, and how to learn to make a difference by fostering authentic connections to faculty and natural resources that will have applications to numerous settings both on and off campus. Included in the course are study skills, time and money management, career planning, and university resources and connection to effective learning strategies.

Undergraduates completing a Bachelor of Science degree in Forestry or Environmental Science in the Arthur Temple College of Forestry and Agriculture (ATCOFA) at Stephen F. Austin State University (SFA), Nacogdoches, Texas, USA, have the opportunity to complete a one credit graded Freshman Seminar course (SFA 101) on how to succeed in college. This course meets twice a week for one hour each time and covers essentials of how to be successful as a freshman college student. Activities and topics covered include college learning strategies, time management, 
financial management, campus and community service opportunities, working successfully with peers, faculty and staff, and the value of a college education. University wide, students completing the SFA 101 course have a two semester cumulative grade point average (GPA) that is 0.15 points higher and an $11 \%$ greater 12 month retention rate than students not taking SFA 101. Sections of SFA 101 can be specialty sections and a section for natural resource management (Forestry and Environmental Science) majors was created. The purpose of this course was to acquaint students with the principles of NRM and to complement future instruction in this field of study. As a hands-on integrative field activity, measurement of water quality variables was coupled with a guided canoe trip on the Neches River in East Texas as both a discussion and practical exercise on the potential for including of the Neches River as a National Wild and Scenic Rivers designation.

\section{Methods}

\subsection{Neches River Exercise}

For the Neches River exercise for the SFA 101 course, students were introduced to the Neches River as an ecosystem. Controversies surrounding the future of the river as a possible candidate for National Wild and Scenic Rivers designation were explored through guest speakers, and various community stakeholder positions were examined. The significance of this problem-based collaborative learning opportunity was emphasized to enhance student interest and to emphasize how "wicked" problems in NRM require collaborative, scientific research based solutions (Newman, Bruyere, \& Beh, 2007).

Students were divided into groups of approximately 5 students for both the research tasks and for the presentations. Research tasks were assigned and explained ahead of time to maximize learning in the field and minimize potential confusion and frustration. Students were instructed in how to effectively conduct collaborative learning projects. The section of the river to be analyzed was planned and evaluated by the class using available canoeing maps, river guide books, and available high resolution multispectral imagery (Kulhavy, Unger, Hung, \& Douglass, 2014). The students were then instructed in safe and effective canoeing, and proper use of safety equipment including like personal flotation devices.

\subsection{Sampling Protocol}

As incoming freshmen, these students had limited technical knowledge, so the instructor chose relatively straight-forward methods for conducting the analysis of approved Environmental Protection Agency (EPA) methods for conducting habitat analysis, keeping the rigor appropriate to a college level course. A standard rapid bioassessment protocol published by EPA for streams and wadeable rivers was employed (Barbour, Gerritsen, Snyder, $\&$ Stribling, 1999). One analysis reach was located in a forested area and another reach was in an agricultural area. A particular strength to this methodology is that students are able to assign a numerical score (on a scale from 1 to 20) to bankside habitat parameters that are readily identifiable in the field, and they can see the differences in land use and how these differences directly influence riparian habitat. This numerical score provides an objective means of evaluating habitat differences. In addition, a YSI ${ }^{\circledR} 600 \mathrm{XL}$ water quality sonde was used to measure real-time water quality parameters including stream temperature $\left({ }^{\circ} \mathrm{C}\right), \mathrm{pH}$, dissolved oxygen $(\mathrm{mg} / \mathrm{L})$ conductivity (micro-mhos) and turbidity (NTU). Students were instructed in the use of this water quality monitoring equipment (Figure 2). The instruments were calibrated by the instructor prior to the exercise, and students were required to interpret the values using state and federal water quality standards. Freshwater mussels were also collected and identified to allow for biological comparisons to be made (Howells, Neck, \& Murray, 1996). Water quality, riparian habitat, and freshwater mussel survey reaches were located with Garmin ${ }^{\circledR}$ eTrex 30 GPS units, so comparisons could be drawn among sites along the river. 


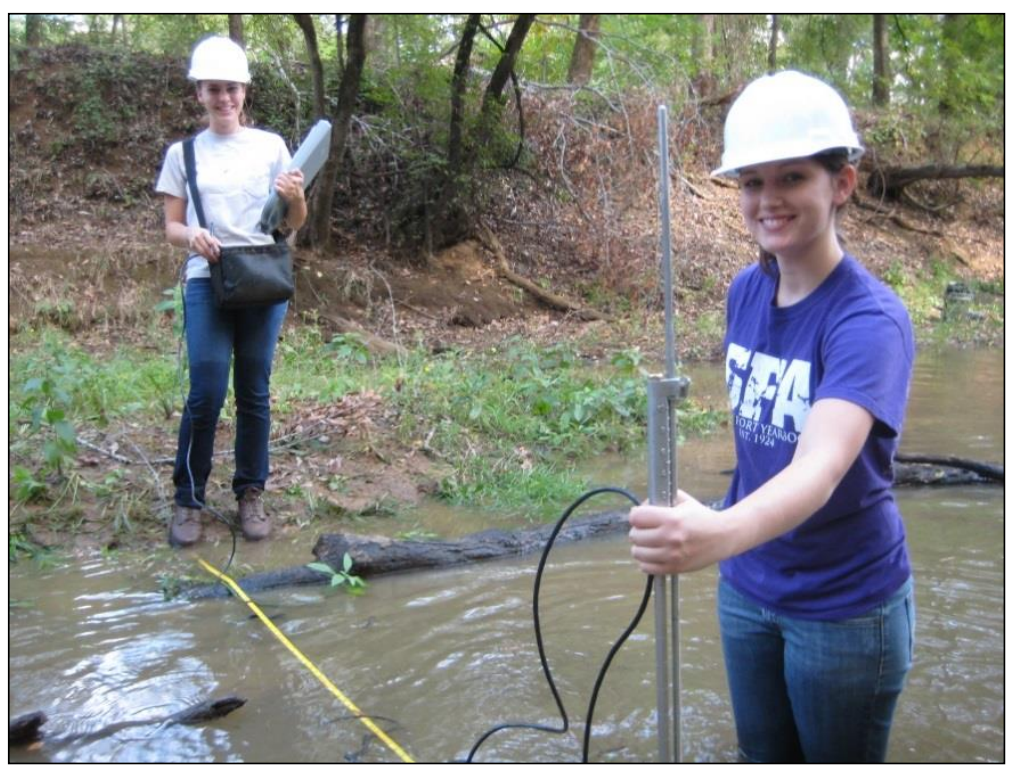

Figure 2. Students at Stephen F. Austin State University using water measuring equipment during field-based collaborative learning exercises.

Students were required to analyze and present their results at a college-level poster symposium and engage in active discussions of their results with other undergraduate and graduate students. Faculty in the college also discussed results with the students. The poster symposium was designed to engage students by combining three broad areas of competency needed by natural resources professions as mentioned above. Student attitudes were assessed with an end of course evaluation that included a qualitative section dealing with what the students found valuable about the course.

\section{Results}

\subsection{Neches River Assessment Results}

In terms of analytical data, using the EPA rapid bioassessment methodology, the students found that the land use along the bank of the river made a dramatic difference. In general, the forested site had a much higher habitat score (180 out of a possible 200) than the site in the agricultural area (143 out of 200) that was cleared to the river bank (Table 1). In particular, students observed how the lack of trees on the streambank reduced the amount of soil protection and increased the amount of bank erosion observed. This resulted in degraded habitat for aquatic life in the river. Students gained a greater awareness of the importance of land use on the quality of habitat for fish and riparian wildlife species as a result.

For the water quality criteria, students found that the sites were similar on the day of the evaluation (Table 2). Therefore, the change in land use did not immediately result in reduced water quality in this case. There are many factors that can account for this, but students gained an appreciation for the fact that in NRM management results are not always as cut and dry as anticipated. Significant changes may take time to be measurable or effects may not necessarily be measurable at the place where the change occurred. This is what makes so many of the NRM challenges associated with water resources "wicked" problems. Much greater depth of insight and research is needed to tease out these sorts of effects, and students gained a greater appreciation of this. This highlights why they will be required to take courses in fields ranging from chemistry to biology and from biometrics to soils and hydrology. They gained a greater understanding of the importance of incorporating these fields into their understanding in order to be successful as a NRM professional. 
Table 1. Habitat assessment scores (based on a relative scale of 1 to 20) of two sites on the Neches River, based on the Environmental Protection Agency's Rapid Bioassessment Protocol for use in streams and wadeable rivers.

\begin{tabular}{lll}
\hline & Site 1 & Site 2 \\
Habitat Parameter & Forested buffer intact & No forested buffer \\
\hline Epifaunal Substrate/Available Cover & 15 & 15 \\
Pool Substrate Characterization & 18 & 18 \\
Pool Variability & 19 & 17 \\
Sediment Deposition & 18 & 16 \\
Channel Flow Status & 18 & 18 \\
Channel Alteration & 20 & 20 \\
Channel Sinuosity & 20 & 18 \\
Bank Stability & 16 & 8 \\
Vegetation Protection & 18 & 8 \\
Riparian Vegetation Width & 18 & 5 \\
Total Score & 180 & 143 \\
\hline
\end{tabular}

Table 2. Water quality results from two sites on the Neches River, with site 1 having a mature forested buffer and site 2 being in an agricultural area with no buffer.

\begin{tabular}{lllll}
\hline Parameter & Units & Site 1 & Site 2 & $\begin{array}{l}\text { Texas Commission on Environmental Quality } \\
\text { Water Quality Standard }\end{array}$ \\
\hline Temperature & ${ }^{\circ} \mathrm{C}$ & 12.64 & 12.72 & $<35$ \\
Conductivity & $\mathrm{mMhos}$ & 196 & 196 & $<500$ \\
$\mathrm{pH}$ & & 7.15 & 7.04 & $6.0-8.5$ \\
Dissolved Oxygen & $\mathrm{mg} / \mathrm{L}$ & 9.13 & 9.14 & $>5.0$ \\
$\%$ DO Saturation & $\%$ & 86 & 86.2 & \\
Turbidity & $\mathrm{NTU}$ & 125 & 120 & $<500$ \\
\hline
\end{tabular}

Similarly, the freshwater mussels collected in the Neches River were characteristic of a stream with good water quality. Species collected included: threehorn wartyback (Obliquaria reflexa), pimpleback (Quadrula pustulosa), mapleleaf (Quadrula quadrula), threeridge (Amblema plicata), paper pondshell (Anodonta imbecillis), Texas pigtoe (Fusconaia askewi), and washboard (Megalonaias nervosa). This means that in spite of the impacts the Neches River has experienced from past human uses (as illustrated by the agricultural area and upstream dams), the biota observed still remain relatively robust. However, discussions about the species not observed due to some of these human induced impacts highlighted the need for additional research into this. Students concluded that the river is therefore worth conserving and that additional resources should be allocated to studying and protecting this resource.

\section{Discussion}

\subsection{Student Learning Outcomes}

In terms of student learning outcomes, the Neches River canoeing trip is the most popular and memorable component of SFA 101 for NRM majors. NRM majors that do not take the NRM section of SFA 101 feel that they missed out on an important learning opportunity after their peers describe the experience to them. In addition, students participating in this exercise feel a greater connection to the river and a greater desire to engage with their NRM classes with a view toward success in the profession. Student comments regarding the river project from the qualitative portion of the end of semester course evaluations included:

"I loved the class, the canoe trip kept things interesting." 
"I developed greater critical thinking abilities as a result of this."

"The experience to get out on a canoe trip and meeting the people to help me in college was very beneficial."

"We built greater teamwork when we went canoeing and this will help me."

There were no negative comments about the Neches River exercise. However, NRM majors tend to be more tolerant of the inherent inconveniences of being outdoors like biting insects, weather, and the discomfort of being wet and muddy. This may not necessarily be the case for students pursuing other majors.

The knowledge, skills, abilities, and behaviors learned in this project are key to being an effective natural resources professional, providing insights into a career-to-come. The project combines scientific and technical rigor, with NRM relevance, while building key relationships with peers, stakeholders with conflicting interests and views, and the general public.

\subsection{Recommendations}

As with any field based learning experience, there are several considerations that must be accounted for by the instructor. First and foremost is safety. Canoeing basics, the importance of good communication, the necessity of proper personal protective equipment (especially life jackets) must be continually emphasized. Students want to enjoy themselves, but the experience must be a safe one for that to happen. Included in student safety is the importance evaluating river flow conditions. The United States Geological Survey (USGS) operates a network of stream gages that give up to the minute flow conditions. Every river has a flow that is too low, optimum, or too high for canoeing. When flows exceed the recommended levels, the trip must be canceled to avoid potential injuries and reduce liability. In addition, high probabilities for inclement weather must be considered. This leads to another logistical consideration, finding a time when the greatest number students are able to participate. Every semester is filled with numerous extra-curricular events, and finding the available windows where river flows and weather are optimum is a challenge. Cost is another challenge. This trip cost approximately $\$ 500$ and funds were provided by the university and by the college to make this happen. Access to water quality equipment and obtaining biological collection permits is another consideration. If these are not available, partnering with other faculty or professionals in the area would be helpful. Finally, a trip like this requires a significant amount of pre-planning and logistical considerations. The total float time on the river is about 5 hours for this trip. However, the instructor had at least 15 hours tied up in planning, training, assembling the canoes and other equipment, and transportation logistics. A final recommendation is that a quantitative assessment tool be developed and utilized to supplement the qualitative assessment in order to more precisely evaluate student learning outcomes.

\subsection{Conclusions}

The Neches River in East Texas is a special place, and the project in SFA 101 helps to build a sense of place that can be extremely important for NRM students. This is only one example of a project that can engage NRM students; however, the critical aspects to any project like this are that students learn to connect to the place and profession, and work in teams with peers on challenging and relevant issues, all while having fun and building what will become great memories through experiential learning. Based on student comments from the qualitative assessment, students formed connections with the resource and people from the Neches River field exercise. They were surprised by the differences in land use that were readily quantifiable, and felt more motivated to take action to help conserve this resource. They also came to understand that one of the key actions they can personally take is to engage with their chosen major and grow as natural resources professionals.

Projects like the Neches River collaborative learning exercise combines technical, general, and personal competencies in active, high impact practices, as illustrated in Figure 1. In addition, based on what other studies have found and the qualitative assessment from this study, students realize that working outdoors, using high technology, and making a difference really is critical for their professional success (Figure 3). By working together effectively, emphasizing the importance of professionalism, and developing effective communication and people skills, students learn the difference between technical (managerial skills) and professional competencies (leadership skills), and seeds are planted that will bear fruit in many aspects of the university courses to come and ultimately for the profession. 


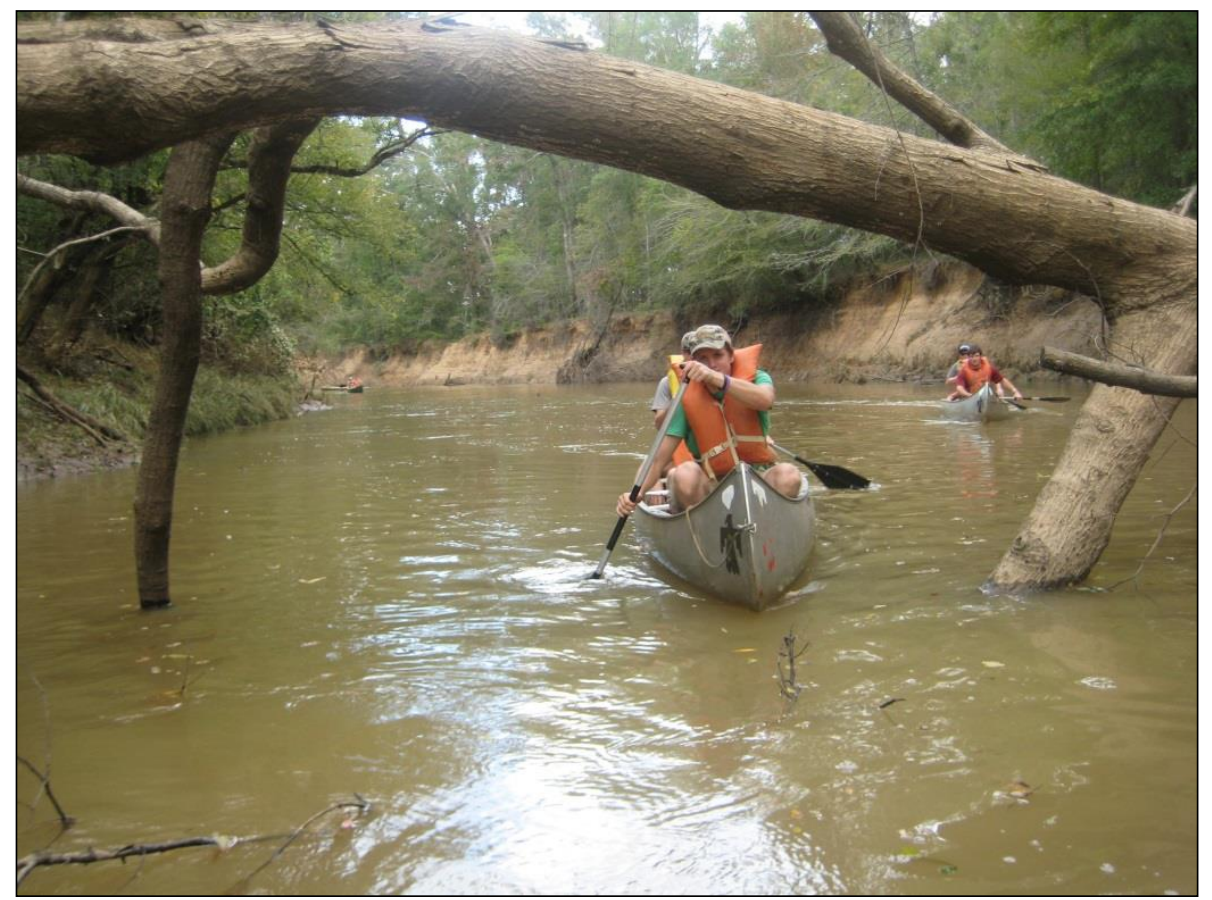

Figure 3. Collaborative teamwork is required for students to complete the Neches River exercise. By the end of the three-hour trip, students develop comradery, a sense of accomplishing an important task, and a connection to the natural resource and profession.

\section{References}

Barbour, M. T., Gerritsen, J., Snyder, B., \& Stribling, J. (1999). Rapid bioassessment protocols for use in streams and wadeable rivers. USEPA, Washington.

Berry, J., \& Houston, K. (1995). Students using posters as a means of communication and assessment. Educational Studies in Mathematics, 29(1), 21-27. http://dx.doi.org/10.1007/BF01273898

Bullard, S. H., Stephens Williams, P., Coble, T., Coble, D. W., Darville, R., \& Rogers, L. (2014). Producing "society-ready" foresters: A research-based process to revise the bachelor of science in forestry curriculum at Stephen F. Austin State University. Journal of Forestry, 112(4), 354-360. http://dx.doi.org/10.5849/jof.13-098

Charrier, George, C. (1972). Cog's Ladder: A Model of Group Growth by George O. Charrier, an employee of Procter and Gamble, written and published for a newsletter in that company in 1972.

Hancock, T., Smith, S., Timpte, C., \& Wunder, J. (2010). PALs: Fostering student engagement and interactive learning. Journal of Higher Education Outreach and Engagement, 14(4), 37-60.

Howells, R. G., Neck, R. W., \& Murray, H. D. (1996). Freshwater Mussels of Texas, Austin, Texas: University of Texas Press.

Kuh, G. D., Cruce, T. M., Shoup, R., Kinzie, J., \& Gonyea, R. M. (2008). Unmasking the effects of student engagement on first-year college grades and persistence. The Journal of Higher Education, 79(5), 540-563. http://dx.doi.org/10.1353/jhe.0.0019

Kulhavy, D. L., Unger, D. R., Hung, I.-K., \& Douglass, D. (2014). Integrating hands-on undergraduate research in an applied spatial science senior level capstone course. International Journal of Higher Education, 4(1), 52-60. http://dx.doi.org/10.5430/ijhe.v4n1p52

Lobry de Bruyn, L., \& Prior, J. (2001). Changing student learning focus in natural resource management education-problems (and some solutions) with using problem based learning. Flexible Learning for a Flexible Society, 441-451. 
Maxwell, J. C. (2003). Thinking for a change: 11 ways highly successful people approach life and work. FaithWords.

Newman, P., Bruyere, B. L., \& Beh, A. (2007). Service-learning and natural resource leadership. Journal of Experiential Education, 30(1), 54-69. http://dx.doi.org/10.5193/JEE.30.1.54

Pascarella, E. T., Pierson, C. T., Wolniak, G. C., \& Terenzini, P. T. (2004). First-generation college students: Additional evidence on college experiences and outcomes. The Journal of Higher Education, 75(3), 249-284. http://dx.doi.org/10.2307/3838816

Robison, D. J. (2005). Teaching Borlaug--or valuing the expertise of breadth. Journal of Forestry, 103(8), 423-424.

Schnell, C. A., \& Doetkott, C. D. (2003). First year seminars produce long-term impact. Journal of College Student Retention: Research, Theory and Practice, 4(4), 377-391. http://dx.doi.org/10.2190/NKPN-8B33-V7CY-L7W1

Schwartz, D. L., Lin, X., Brophy, S., \& Bransford, J. D. (1999). Toward the development of flexibly adaptive instructional designs. Instructional-design Theories and Models: A New Paradigm of Instructional Theory, 2, 183-213.

Semken, S., \& Freeman, C. B. (2008). Sense of place in the practice and assessment of place - based science teaching. Science Education, 92(6), 1042-1057. http://dx.doi.org/10.1002/sce.20279

Sharik, T. L., \& Frisk, S. L. (2011). Student perspectives on enrolling in undergraduate forestry degree programs in the United States. Journal of Natural Resources and Life Sciences Education, 40(1), 160-166. http://dx.doi.org./10.4195/jnrlse.2010.0018u

Sweeder, R. D., \& Strong, P. E. (2012). Impact of a sophomore seminar on the desire of STEM majors to pursue a science career. Journal of STEM Education: Innovations and Research, 13(3), 52-61.

Thomas, A., \& Thorne, G. (2009). How to increase higher order thinking. Metarie, Louisiana: Center for Development and Learning

Thompson, J., Jungst, S., Colletti, J., Licklider, B., \& Benna, J. (2003). Experiences in developing a learning-centered natural resources curriculum. Journal of Natural Resources and Life Sciences Education, 32, 23-31.

Unger, D. R., Hung, I.-K., Zhang, Y., \& Kulhavy, D. L. (2014). Evaluating GPS effectiveness for natural resource professionals: Integrating undergraduate students in the decision-making process. Journal of Studies in Education, 4(4), 30-44. http://dx.doi.org/10.5296/jse.v4i4.6389

Unger, D. R., Kulhavy, D. L., Hung, I.-K., \& Zhang, Y. (2014). Quantifying natural resources using field-based instruction and hands-on applications. Journal of Studies in Education, 4(2), 1-15. http://dx.doi.org/10.5296/jse.v4i2.5309

Vanclay, J. K. (2007). Educating Australian foresters for the 21st century. International Forestry Review, 9(4), 884-891. http://dx.doi.org/10.1505/ifor.9.4.884

Wolter, B. H. K., Millenbah, K. F., Montgomery, R. A., \& Schneider, J. W. (2011a). Factors affecting persistence of undergraduate students in a fisheries and wildlife program: Freshmen. Journal of Natural Resources and Life Sciences Education, 40(1), 206-214. http://dx.doi.org/10.4195/jnrlse.2010.0030n

Wolter, B. H. K., Millenbah, K. F., Montgomery, R. A., \& Schneider, J. W. (2011b). Factors affecting persistence of undergraduate students in a fisheries and wildlife program: Leavers. Journal of Natural Resources and Life Sciences Education, 40(1), 10-18. http://dx.doi.org/10.4195/jnrlse.2010.0025u 